\title{
Pengaruh variabel Makro Ekonomi terhadap indeks harga saham LQ-45 di Bursa Efek Indonesia
}

\author{
Hamzah $^{*}$, Devi Valeriani ${ }^{1}$, \& Andi Yusfany² \\ ${ }^{1}$ Fakultas Ekonomi, Universitas Bangka Belitung, Indonesia \\ 2BAPPEDA Provinsi Kepulauan Bangka Belitung, Indonesia \\ * hamzahsuju@gmail.com
}

\begin{abstract}
Abstrak Bursa Efek Indonesia merupakan lembaga yang memfasilitasi perdagangan efek di Indonesia. Saham merupakan salah satu instrumen investasi yang memberikan imbal hasil yang cenderung meningkat setiap tahunnya. Penelitian ini bertujuan untuk menganalisis pengaruh variabel makro ekonomi dari suku bunga, nilai tukar, cadangan devisa, dan harga emas terhadap indeks harga saham LQ-45 di Bursa Efek Indonesia. Metode penelitian yang digunakan adalah metode penelitian kuantitatif dengan teknik analisis regresi linear berganda. Hasil penelitian menunjukkan bahwa secara parsial suku bunga memiliki pengaruh yang negatif signifikan terhadap indeks harga saham LQ-45. Nilai tukar memberikan pengaruh positif serta signifikan terhadap indeks harga saham LQ-45. Cadangan devisa berpengaruh positif signifikan terhadap indeks harga saham LQ45. Sedangkan harga emas memberikan pengaruh yang negatif namun tidak signifikan terhadap indeks harga saham LQ-45. Hasil pengujian secara simultan, menemukan bahwa suku bunga, nilai tukar, cadangan devisa, dan harga emas berpengaruh signifikan terhadap indeks harga saham LQ-45.
\end{abstract}

Kata kunci: makro ekonomi; investasi saham; indeks LQ-45; Bursa Efek Indonesia

\begin{abstract}
The Indonesia Stock Exchange is an institution that fasilitates securities trading in Indonesia. Stocks are an investment instrument that provides returns Which tend to increase every year. This study aims to analyze the effect of macroeconomic variables from interest rates, exchange rates, foreign exchange reserves, and gold prices on the LQ-45 stock price index on the Indonesia Stock Exchange. Quantitative research methods aplied with multiple linear regression analysis techniques. The results showed that partially interest retes have a significant negative effect on the LQ-45 stock price index. The exchange rate has a positive and significant impact on the of $L Q-45$ stock price index. Foreign exchange reserves have a significant positive effect on the LQ-45 stock price index. Meanwhile, the price of gold has a negative but insignificant effect on the LQ-45 stock price index. The simultaneous test results found that interest rates, exchange rate, foreign exchange, and gold price have a significant effect on the LQ-45 stock price index.
\end{abstract}

Keywords: macro economy; stock investment; ; index LQ-45; Indonesia Stock Exchange

JEL Classification: $\mathrm{C} 10 ; \mathrm{E} 46$; $\mathrm{O} 10$ 


\section{PENDAHULUAN}

Pasar modal merupakan sarana pemodalan yang mewadahi setiap negara untuk memperoleh akses pemodalan sebagai penggerak sektor perekonomian secara global. Arus globalisasi telah membuat sebagian besar pasar modal di dunia memiliki hubungan yang semakin ketergantungan dan saling berhubungan, sehingga investor perlu mempertimbangkan faktor-faktor penting dalam menentukan keputusan investasi dalam pasar modal (Nuryasman \& Permatasari, 2016). Perkembangan investasi di Indonesia digunakan sebagai sarana yang efektif dalam meningkatkan proses pembangunan negara. Tidak hanya itu, investasi juga akan menghasilkan keuntungan bagi para penanam modal atau investor. Saham merupakan salah satu alternatif investasi yang dapat menjadi bahan pertimbangan bagi calon investor. Menurut Andriyani \& Armereo (2016) saham didefinisikan sebagai bukti kepemilikan atau tanda sebagai penyertaan individu atau lembaga dalam suatu perusahaan dan kegiatan usaha.

Bursa Efek Indonesia merupakan salah satu lembaga terpercaya yang akan memfasilitasi para Investor dan emiten dalam melakukan perdagangan efek. Bursa Efek Indonesia memberikan fasilitas berupa perdagangan efek (Equity), perdagangan obligasi (Fixed Income), serta perdagangan derivatif (Derivative Instruments) (Yanita \& Wahyuddin, 2010). Bursa Efek Indonesia menjadi perantara dalam memfasilitasi perusahaan yang membutuhkan modal (emiten) dan investor yang memiliki kelebihan modal. Perusahaan akan mendapatkan modal dengan cara menawarkan sahamnya sedangkan investor akan mendapatkan tingkat imbal hasil berupa return saham tersebut. Jauhari (2018) menyatakan bahwa Bursa Efek Indonesia tidak hanya sebagai perantara antara investor dan emiten, tetapi juga menyediakan berbagai informasi terbaru mengenai perkembangan bursa kepada masyarakat dengan menampilkan data pergerakan kinerja harga saham perusahaan.Investor selalu memperhatikan pergerakan Indeks Harga Saham Gabungan (IHSG) sebagai pedoman dalam melihat perkembangan kinerja perusahaan sebelum melakukan investasi di Bursa Efek Indonesia (BEI). IHSG adalah indeks yang memperlihatkan perkembangan keseluruhan harga saham yang sudah tercatat dan terdaftar di Bursa Efek Indonesia. Dengan demikian, IHSG merefleksikan kinerja secara keseluruhan harga saham di Bursa Efek Indonesia (Handiani, 2014).

Zakaria et al (2018) mengemukakan pendapatnya bahwa IHSG menjadi indikator penting di Bursa Efek Indonesia. Pergerakan IHSG yang meningkat atau menurun akan mempengaruhi investor dalam membuat keputusan untuk membeli, menahan, atau menjual sahamnya. Asmara \& Suarjaya (2018) menjelaskan bahwa indeks harga saham yang cenderung menurun mengidentifikasikan sebagian besar harga saham juga mengalami penurunan, sebaliknya pergerakan indeks harga saham yang meningkat mengidentifikasikan bahwa sebagian besar harga saham juga meningkat. IHSG yang selalu menjadi tolak ukur dalam mengetahui kondisi pasar masih memiliki kekurangan dalam menginterprestasikan harga saham perusahaan di Bursa Efek Indonesia. Pelaku pasar memiliki kesulitan dalam menentukan saham-saham pilihan karena cangkupan IHSG yang terlalu luas. BEI 
memperkenalkan indeks harga saham LQ-45 sebagai alternatif yang merupakan bagian dari IHSG untuk memudahkan investor dalam memilih saham pilihan. Indeks harga saham LQ-45 diresmikan pertama kali periode bulan Februari 1997 (www.idx.co.id, 10 November 2020).

IHSG mencakup seluruh saham yang sebagian besar kurang aktif dalam perdagangan, sedangkan Indeks LQ-45 lebih spesifik dengan mengelompokkan 45 saham perusahaan teratas. Situngkir \& Batu (2020) berpendapat bahwa saham yang masuk kategori indeks harga saham LQ-45 adalah saham-saham perusahaan yang diseleksi berdasarkan ketentuan likuiditas tertinggi, kapitalisasi pasar besar, frequensi perdagangan tertinggi, serta kondisi keuangan yang stabil.

Bursa Efek Indonesia selalu melakukan pergantian setiap 6 bulan sekali terhadap saham perusahaan yang tergabung kedalam indeks LQ-45 (Yanita \& Wahyudddin, 2010). Artinya, saham perusahaan akan otomatis tergantikan apabila saham tersebut tidak mencapai kriteria seleksi berdasarkan ketetapan Bursa Efek Indonesia dalam menentukan indeks LQ-45. Indeks LQ-45 berfungsi sebagai indikator tren pasar saham teratas untuk mengetahui keadaan 45 saham liquid saat ini apakah sedang aktif atau sedang melesu.

Kinerja Indeks LQ-45 dengan IHSG menunjukkan pergerakan yang berfluktuasi selama periode tahun 2010-2019. Selama periode tahun 2010-2019 Indeks LQ-45 mengalami peningkatan sebesar 53,39 persen lebih rendah dibandingkan dengan IHSG yang telah mengalami peningkatan sebesar 70,10 persen. Berikut adalah gambar perbandingan kinerja Indeks LQ-45 dan IHSG:

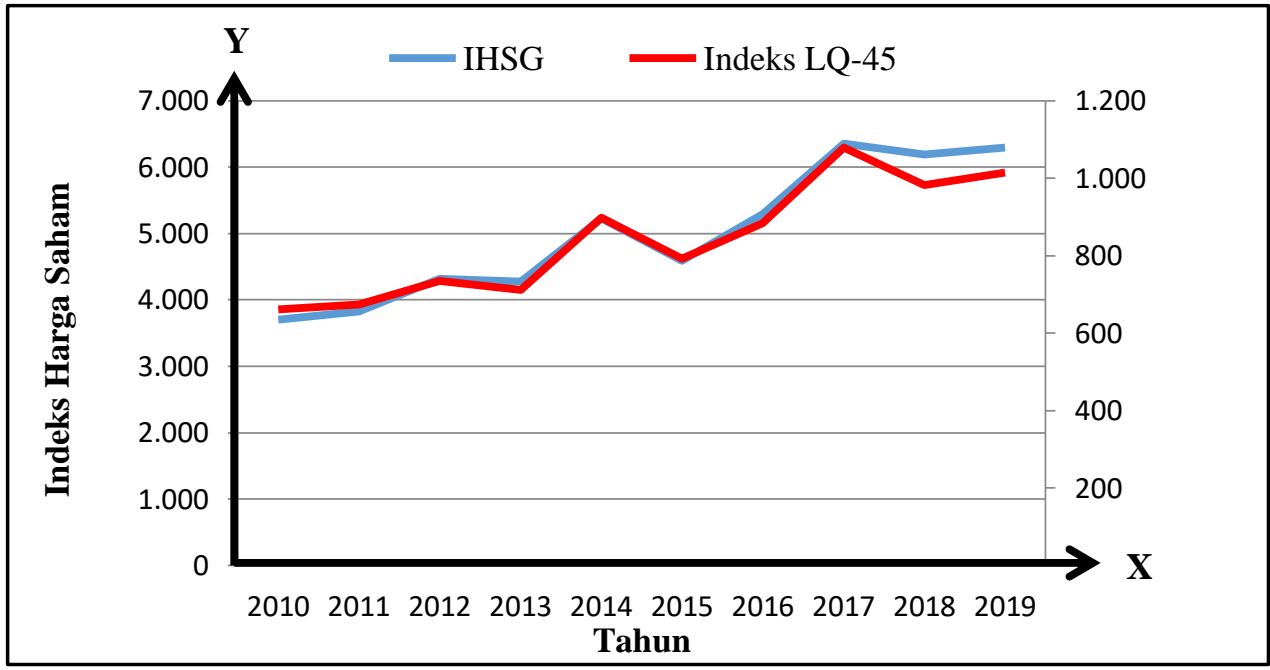

Gambar 1.1 Kinerja Indeks LQ-45 dan IHSG

Sumber : m.id.investing.com diakses 10 November 2020, data diolah

Gambar 1.1 menunjukkan perbandingan kinerja indeks LQ-45 dan IHSG di bursa efek periode tahun 2010-2019, mengalami penurunan yang cukup jauh dibawah IHSG. Kondisi ekonomi yang cenderung tidak stabil membuat indeks LQ45 jauh menurun dibawah IHSG. Permasalahan ini terjadi karena akibat kenaikan suku bunga acuan tahun 2018 yang mencapai 6,00 persen lebih tinggi dibandingkan 
tahun 2017 hanya berkisar 4,25 persen (Indikator Moneter Bank Indonesia, 2020). Selain itu, tekanan juga terdapat dari berbagai sisi yang menyebabkan nilai rupiah melemah terhadap dolar Amerika yang menyentuh nilai RP. $15.227,00$ pada periode bulan Oktober 2018 (Portal Statistik Perdagangan, diakses 10 November 2020).

Kondisi melemahnya nilai rupiah terhadap dolar Amerika merupakan fenomena terburuk sepanjang sepuluh tahun terakhir. Kondisi ini menjadi pemicu indeks LQ-45 cenderung melemah dibawah IHSG. Hal ini mengidentifikasikan bahwa Indeks LQ45 cenderung lebih mudah terkoreksi terhadap perubahan gejolak perekonomian dibandingkan dengan IHSG. Setelah menurun cukup jauh pada tahun 2018, indeks LQ-45 menunjukkan perbaikan pada periode selanjutnya walaupun diperkirakan akan kembali melemah karena masih dibawah IHSG. Secara rata-rata selama sepuluh tahun terakhir return saham Indeks LQ-45 lebih rendah daripada return saham di IHSG. Namun, kinerja Indeks LQ-45 pada tahun 2014 mampu memberikan return saham sebesar 26,36 persen lebih tinggi daripada IHSG yang hanya memiliki return sebesar 22,29 persen. Sedangkan, pada tahun 2015 return saham IHSG dan Indeks LQ-45 terendah memiliki nilai yang sama sebesar -12,13 persen selama periode tahun 2011-2019.

Melemahnya indeks LQ-45 yang berada cukup jauh dibawah IHSG pada tahun 2018-2019 juga disebabkan oleh adanya penerapan kebijakan free float oleh Bursa Efek Indonesia sebagai faktor tambahan dalam menyusun bobot penilaian terhadap indeks LQ-45 masing-masing emiten. Menurut Mutira (2019) Free Float merupakan total saham yang dimiliki oleh publik dengan rasio kurang dari 5 persen. Rasio free float diperoleh berdasarkan hasil perbandingan total saham free float relatif dengan total saham yang tercatat. Kebijakan tersebut membuat para investor dan manajer investasi melepas emiten yang memiliki nilai free float rendah. Akibatnya, pasar saham langsung bereaksi mengalami penurunan setelah pengumuman kebijakan ini oleh Bursa Efek Indonesia pada November 2018.

Kinerja Indeks LQ-45 apabila diperhatikan dengan seksama selalu mengikuti pola kinerja IHSG. Artinya, pada saat terjadi penurunan atau peningkatan pada IHSG maka akan terjadi pula pada Indeks LQ-45. Fenomena tersebut menunjukkan kinerja Indeks LQ-45 beserta saham-saham yang terdaftar didalamnya mampu mempresentasikan kinerja pasar untuk mempermudah investor dalam melakukan screening saham-saham pilihan, serta dapat digunakan oleh pelaku pasar lainnya seperti manajer investasi sebagai acuan untuk membuat produk investasi misalnya reksa dana. Fenomena ini menemukan fakta yang menarik untuk menjawab pertanyaan yang kemudian akan dibahas dalam penelitian ini. Investor yang menaruh pilihan pada Indeks LQ-45 tidak dapat dipastikan bahwa saham-saham perusahaan yang tergabung didalamnya terus mengalami peningkatan. Akan tetapi, Indeks LQ-45 akan memudahkan pelaku investasi untuk menganalisis sahamsaham perusahaan yang memiliki kinerja baik dibandingkan saham-saham perusahaan diluar Indeks LQ-45.

Investor yang akan berinvestasi memerlukan informasi yang relevan mengenai kondisi perekonomian termasuk informasi ekonomi secara makro yang dapat mempengaruhi kinerja saham perusahaan dalam membuat keputusan investasi. 
Kusumawardhani (2018) menyatakan seorang investor harus mampu memprediksi kondisi perekonomian dan prospek perusahaan yang menawarkan surat berharga untuk menghindari kerugian serta salah dalam menentukan investasi. Iglesias \& Haughton (2013) mengemukakan pendapatnya bahwa kenaikan dan penurunan harga saham berdampak pada ekonomi makro melalui efek kekayaan investor dan kemampuan perusahaan dalam membiayai proyek investasi.

Suku bunga, nilai tukar rupiah, cadangan devisa, serta harga emas merupakan faktor makro ekonomi yang harus menjadi perhatian investor, karena perubahan yang terjadi dalam ekonomi makro akan berdampak pada perubahan harga saham perusahaan. Sejalan dengan pendapat Andriyani \& Armereo (2016) menjelaskan bahwa kondisi ekonomi makro mampu mempengaruhi kinerja perusahaan seharihari, oleh karena itu investor harus mampu memahami dan memprediksi perkembangan perekonomian dimasa depan akan bermanfaat untuk menentukan keputusan investasi..

Suku bunga adalah penyerahan bunga secara tahunan terhadap suatu pinjaman yang dipersentasekan kedalam total bunga yang diperoleh setiap akhir periode dibagi dengan total pinjaman yang secara langsung dikendalikan oleh Bank Indonesia (Sunardi \& Ula, 2017). Suku bunga di Indonesia selama periode tahun 2010-2019 cenderung mengalami penurunan. Pergerakan dari suku bunga berfluktuasi dan menunjukkan tren yang menurun selama periode tahun 2010-2019. Suku bunga pada tahun 2014 mencapai titik tertinggi sebesar 7,75 persen. Sedangkan, suku bunga terendah sebesar 4,25 persen yang terjadi pada tahun 2017 (Indikator Moneter Bank Indonesia, 2020). Pergerakan suku bunga acuan yang selalu berubah dapat mempengaruhi kinerja indeks harga saham di bursa efek. Peningkatan suku bunga membuat investor melakukan pengalihan dana dari pasar modal ke perbankan dalam bentuk deposito. Pengalihan dana tersebut oleh investor menyebabkan indeks harga saham menjadi turun. Silim (2013) dan Hsing \& Hsieh (2012) menegaskan bahwa suku bunga akan berdampak negatif terhadap pergerakan harga saham. Peningkatan suku bunga menyebabkan harga saham menjadi turun, sebaliknya harga saham akan mengalami peningkatan apabila suku bunga menurun.

Nilai Tukar merupakan perbandingan nilai mata uang pada suatu negara terhadap nilai mata uang negara yang berbeda (Pratiwi \& Hendrawan, 2014). Nilai tukar sangat penting diamati pergerakannya, karena investor yang terdapat di Bursa Efek Indonesia terdiri dari berbagai macam kalangan baik yang berasal dari dalam negeri maupun dari negara lain. Oleh karena itu. nilai tukar menjadi bahan pertimbangan dalam berinvestasi karena hasil pengembalian saham dikonversikan dalam suatu nilai tukar. Nilai tukar rupiah terhadap dolar berfluktuasi selama periode tahun 2010-2019. Tren nilai tukar rupiah mengalami depresiasi tertinggi terhadap dolar pada Oktober 2018 yang mencapai Rp. 15.227,00 (Statistik Kementerian Perdagangan, diakses 10 November 2020).

Nilai tukar rupiah yang menunjukkan peningkatan justru akan mengakibatkan indeks harga saham menjadi turun. Nilai tukar rupiah terhadap dolar yang terdepresiasi cenderung membuat investor memindahkan dananya dari saham 
domestik ke saham asing, sehingga indeks harga saham mengalami penurunan. Hal ini ditegaskan oleh Akbar et al (2016) dan Sholikin (2016) bahwa pergerakan nilai tukar akan berdampak negatif terhadap pergerakan harga saham. Pergerakan nilai tukar rupiah yang meningkat akan menyebabkan harga saham menjadi menurun, sebaliknya nilai tukar yang cenderung menurun menyebabkan harga saham menjadi meningkat.

Cadangan devisa didefinisikan sebagai sebuah indikator ekonomi makro yang menunjukkan kekuatan perekonomian sebuah negara dalam membiayai kebutuhan dalam negerinya (Zakaria et al, 2018). Cadangan devisa Indonesia selama periode tahun 2010-2019 menunjukkan peningkatan. Pendapatan cadangan devisa di Indonesia mencapai nilai tertinggi sebesar $130.196,00$ juta USD yang terjadi pada tahun 2017. Sedangkan pendapatan cadangan devisa mencapai titik terendah yang terjadi pada tahun 2010 sebesar $96.207,00$ juta USD. Selama periode pengamatan pendapatan cadangan devisa di Indonesia telah mengalami peningkatan sebesar 85,75 persen (Indikator Moneter Bank Indonesia, 2020).

Cadangan devisa yang meningkat menggambarkan neraca pembayaran yang surplus. Surplus neraca pembayaran akan mendorong investor tertarik untuk menginvestasikan dananya sehingga perdagangan saham di Bursa Efek Indonesia akan mengalami peningkatan yang juga akan meningkatkan harga saham. Sebagaimana yang ditegaskan oleh Mikial (2014) dan Zakaria et al (2018) bahwa cadangan devisa yang mengalami peningkatan akan menyebabkan harga saham juga meningkat secara signifikan.

Emas merupakan komoditas barang yang diperjualbelikan dalam bentuk pilihan investasi rill selain saham pada investasi finansial. Pratiwi \& Hendrawan (2014) mengemukakan pendapatnya bahwa harga emas dipengaruhi oleh harga emas dunia yang juga akan mempengaruhi harga saham perusahaan. Harga emas dunia menjadi perhatian penting dalam keputusan investasi. Kenaikan harga emas berpotensi untuk membuat investor beralih investasi pada emas dari pada saham sehingga akan mempengaruhi kinerja indeks harga saham.

Harga emas selama periode tahun 2010-2019 mengalami fluktuasi yang rendah dan cenderung meningkat. Harga emas mencapai harga tertinggi sebesar Rp. 714.470,50 pada Agustus 2019. Harga emas terendah sebesar Rp. 326.232,66 pada Januari 2010 (m.id.investing.com, diakses 10 November 2020). Harga Emas yang menunjukkan peningkatan akan mengakibatkan harga saham menjadi turun. Harga emas yang meningkat, akan membuat perilaku investor mengalihkan investasinya pada emas, sehingga mengakibatkan penurunan pada indeks harga saham. Sejalan dengan pendapat Venkatraja (2014) bahwa kenaikan harga emas memberikan dampak yang negatif terhadap pergerakan harga saham. Handiani (2014) menegaskan bahwa kenaikan harga emas menyebabkan investor beralih investasi dari saham ke emas, sehingga indeks harga saham menjadi turun. Nugraha (2020) menyatakan hal yang berbeda bahwa kenaikan harga emas justru tidak berdampak terhadap perubahan harga saham.

Berdasarkan permasalahan yang telah dipaparkan, penelitian ini bertujuan untuk menganalisis pengaruh secara parsial dan simultan dari suku bunga, nilai 
tukar rupiah, cadangan devisa, dan harga emas terhadap harga saham indeks LQ45 di Bursa Efek Indonesia.

\section{METODE}

Penelitian ini menggunakan fokus penelitian pendekatan kuantitatif. Penelitian dilakukan di Indonesia dengan objek penelitian di Bursa Efek Indonesia. Sumber data yang digunakan dalam penelitian ini tergolong data sekunder yang diperoleh dari halaman web Bank Indonesia untuk mendapatkan data suku bunga dan cadangan devisa, web investing.com dalam mendapatkan data indeks harga saham LQ-45 dan harga emas, serta web Kementerian Perdagangan Indonesia untuk mendapatkan data nilai tukar rupiah.

Populasi penelitian ini mencakup seluruh data indeks harga saham LQ-45, suku bunga, nilai tukar, cadangan devisa, dan harga emas periode bulanan selama tahu 1997-2019 sebanyak 276 populasi. Pengambilan sampel dalam penelitian ini menggunakan teknik purposive sampling yaitu teknik pengambilan sampel yang berdasarkan pertimbangan-pertimbangan tertentu. Sampel dalam penelitian ini adalah data periode bulanan indeks harga saham LQ-45, suku bunga, nilai tukar, cadangan devisa, dan harga emas selama periode 2010-2019 dengan total sampel sebanyak 120 sampel.

Penelitian ini menggunakan metode analisis regresi linear berganda. Berikut model persamaan regresi dalam penelitian ini :

$$
L Q_{t}=\beta_{0}+\beta_{1} S B_{t}+\beta_{2} N_{t}+\beta_{3} C D_{t}+\beta_{4} H_{t}+\mu_{t}
$$

Pengolahan data dalam penelitian ini dilakukan dengan mentransformasi data kedalam bentuk logaritma natural (Ln). Hal ini dikarenakan data yang tersedia memiliki sartuan yang berbeda-beda. Menurut Novianto (2011) model logaritma (log) mempunyai beberapa keuntungan yaitu koefisien-koofisien log memiliki interpretasi yang lebih sederhana, model log mampu mengurangi masalah statistik umum yang dikenal heteroskedastisitas, dan model log mudah dihitung. Namun, data suku bunga tidak dilakukan transformasi kedalam bentuk Ln karena sudah dalam bentuk satuan persentase, Wulandari \& Saleh (2015). Berikut model persamaan regresi setelah dilakukan transformasi data delam bentuk Ln :

$$
\mathrm{Ln}_{\mathrm{LQ}}=\beta_{0}+\beta_{1} \mathrm{SB}_{\mathrm{t}}+\beta_{2} \mathbf{L n}_{\mathrm{NT}_{\mathrm{t}}}+\beta_{3} \mathrm{Ln}_{\mathrm{CD}_{\mathrm{t}}}+\beta_{4} \mathrm{Ln}_{\mathrm{HE}_{\mathrm{t}}}+\mu_{\mathrm{t}}
$$

\section{Dimana :}

$$
\begin{array}{ll}
\text { Ln_LQ } & =\text { Indeks Harga Saham LQ-45 } \\
\text { SB } & =\text { Suku Bunga (BI rate) } \\
\text { Ln_NT } & =\text { Nilai Tukar Rupiah terhadap Dolar Amerika } \\
\text { Ln_CD } & =\text { Cadangan Devisa } \\
\text { Ln_HE } & =\text { Harga Emas (Harga Emas Dunia) } \\
t & =\text { Periode waktu } \\
\beta_{0} & =\text { Konstanta } \\
\beta_{1} \ldots . . . \beta_{4} & =\text { Koefisien Regresi Variabel Independen }
\end{array}
$$




$$
\mu_{\mathrm{t}} \quad=\text { Kesalahan (error) }
$$

Koefisien korelasi digunakan dalam suatu penelitian untuk mengukur derajat keterkaitan diantara dua variabel (Gujarati \& Porter, 2015).

Menurut Gujarati \& Porter (2015) koefisien korelasi dapat diketahui dengan rumus berikut:

Dimana :

$$
\mathbf{R}= \pm \sqrt{\mathbf{r}^{2}}
$$

$\mathrm{R}=$ Koefisien korelasi

$\mathrm{R}^{2}=$ Koefisien determinasi

Koefisien determinasi $\left(\mathrm{r}^{2}\right)$ bertujuan untuk mengukur keberadaan variasi dari variabel dependen seberapa nesar yang dapat dijelaskan oleh variasi dari variabel independen dengan nilai yang berkisar antara 0 - 1 (Gujarati \& Porter, 2015). Koefisien determinasi dapat diketahui dengan rumus berikut :

Dimana :

$$
\mathbf{r}^{2}=\frac{\text { SSR }}{\text { TSS }}
$$

$\mathrm{r}^{2} \quad=$ Koefisien determinasi

$\mathrm{SSR}=$ Sum of Square due to Regression

TSS $=$ Total Sum of Square

\section{HASIL DAN PEMBAHASAN}

\section{Uji Asumsi Klasik}

\section{Uji Normalitas}

Penelitian ini menggunakan metode Test of Normality Kolmogorof-Smirnov untuk melakukan pengujian normalitas. Hasil pengujian menunjukkan bahwa Asymp Sig bernilai $0.200>0,05$, artinya dapat disimpulkan bahwa semua variabel yang digunakan dalam penelitian ini yaitu indeks harga saham LQ-45, suku bunga, nilai tukar, cadangan devisa, dan harga emas memiliki distribusi data yang normal dan menunjukkan bahwa model regresi layak (Santoso, 2012).

\section{Uji Multikolonearitas}

Uji moltikolonearitas dalam penelitian ini dilihat melalui besaran nilai VIF dan Tolerance. Hasil uji multikolonearitas menunjukkan hasil bahwa semua variabel independen pada model regresi tidak terdapat masalah multikolonearitas yang ditunjukkan oleh nilai VIF dibawah 10 dan nilai Tolerance lebih besar dari 0,1 (Santoso, 2012).

\section{Uji Heteroskedastisitas}

Uji heteroskedastisitas dalam penelitian ini menggunakan metode uji Glejser (Gujarati, 2015). Hasil pengujian ditemukan bahwa nilai signifikan dari variabel suku bunga, nilai tukar, cadangan devisa, dan harga emas lebih besar dari 0.05. Hal ini dapat disimpulkan bahwa seluruh variabel independen yang digunakan dalam penelitian ini bebas dari masalah heteroskedastisitas. 


\section{Uji Autokerelasi}

Uji autokorelasi pada penelitian ini menggunakan metode uji Durbin watson. Berikut tabel hasil uji autokorelasi dengan metode Durbin Watson. Hasil perhitungan diperoleh nilai Durbin Watson sebesar 0.498 yang berada pada interval -2 sampai dengan +2 . Hal ini mengidentifikasikan bahwa model regresi yang digunakan tidak mengalami autokorelasi sehingga model layak digunakan (Santoso, 2012).

\section{Pengujian Model Persamaan Regresi}

Hasil pengujian pada analisis regresi linear berganda dilakukan untuk mengetahui pengaruh variabel independen terhadap variabel dependen. Berdasarkan pengujian model persamaan regresi suku bunga, nilai tukar, cadangan devisa, dan harga emas terhadap indeks harga saham LQ-45 diperoleh model persamaan sebagai berikut sebagai berikut :

Ln_LQ $=-5,827-0,014$ SB $+0,595$ Ln_NT $+0,751$ Ln_CD $-0,127$ Ln_HE $\ldots$. (3)

Nilai konstanta pada persamaan model regresi tersebut bernilai sebesar $-5,827$ yang menunjukkan bahwa apabila variabel suku bunga, nilai tukar, cadangan devisa, dan harga emas tidak mengalami perubahan atau nialinya nol, maka variabel indeks harga saham akan mengalami penurunan sebesar -5,827.

1. Nilai koefisien regresi pada variabel suku bunga sebesar $-0,014$ yang mengartikan bahwa apabila variabel suku bunga meningkat sebesar 1 persen, maka variabel indeks harga saham LQ-45 akan mengalami perubahan negatif sebesar -0,014 persen dengan asumsi variabel independen lainnya konstan.

2. Nilai koefisien regresi pada variabel nilai tukar sebesar 0,595 menunjukan bahwa apabila nilai tukar meningkat sebesar 1 persen, maka indeks harga saham LQ-45 juga akan mengalami peningkatan sebesar 0,595 persen dengan asumsi variabel independen lainnya konstan.

3. Nilai koefisien regresi pada variabel cadangan devisa sebesar 0,751 . Hal ini menunjukkan bahwa apabila variabel cadangan devisa mengalami peningkatan sebesar 1 persen, maka akan meningkatkan indeks harga saham LQ-45 sebesar 0,751 persen dengan asumsi variabel independen lainnya konstan.

4. Nilai koefisien regresi pada variabel harga emas sebesar $-0,127$. Hal ini menunjukkan bahwa apabila variabel harga emas meningkat sebesar 1 persen, maka indeks harga saham akan mengalami penurunan sebesar 0,127 persen dengan asumsi variabel independen lainnya konstan.

\section{Koefisien Korelasi}

Hasil nilai koefisien korelasi sebesar 0,939, maka dapat disimpulkan bahwa korelasi antara varaibel suku bunga, nilai tukar, cadangan devisa, harga emas, dan indeks harga saham LQ-45 adalah termasuk kategori korelasi sangat kuat karena berada pada interval 0,800 - 1,000 (Sugiyono, 2014). 


\section{Hasil Koefisien Determinasi}

Hasil koefisien determinasi sebesar 0,879. Hal ini menunjukkan bahwa variabel suku bunga, nilai tukar, cadangan devisa, dan harga emas mampu menjelaskan variasi variabel indeks harga saham LQ-45 sebesar 87,9 persen, sedangkan 12,1 persen lainnya dijelaskan oleh varaibel lain yang tidak dimasukkan dalam peneltian ini.

\section{Uji t}

Hasil perhitungan pengujian secara parsial variabel independen terhadap variabel dependen menemukan bahwa koefisien regresi pada variabel suku bunga diperoleh nilai $t_{\text {hitung }}$ sebesar -2.099 dengan tingkat signifikansi 0.038 . Hasil uji $t$ pada variabel suku bunga dapat ditarik kesimpulan bahwa suku bunga berpengaruh negatif signifikan terhadap indeks harga saham LQ-45 di Bursa Efek Indonesia. Hal ini dikarenakan kenaikan suku bunga acuan oleh Bank Indonesia akan diikuti pula kenaikan suku bunga tabungan oleh Bank-bank komersil. Suku bunga tabungan yang meningkat akan mendorong masyarakat untuk menabung daripada berinvestasi yang menyebabkan perdagangan saham menjadi menurun sehingga indeks harga saham juga menjadi turun. Hasil penelitian ini sejalan dengan penelitian Sunardi \& Ula (2017) yang menyatakan bahwa suku bunga memberikan pengaruh yang negatif serta signifikan terhadap indeks harga saham. Namun, hasil penelitian ini tidak sejalan dengan penelitian Yanita \& Wahyuddin (2010) yang menerangkan bahwa suku bunga justru memberikan pengaruh yang positif terhadap indeks harga saham.

Pengujian koefisien regresi pada variabel nilai tukar memperoleh hasil nilai $t_{\text {hitung }}$ sebesar 10.182 dengan tingkat signifikansi sebesar 0.000 . Hasil perhitungan ini memberikan pengertian bahwa nilai tukar berpengaruh positif signifikan terhadap indeks harga saham LQ-45 di Bursa Efek Indonesia. Hasil penelitian ini tidak sesuai dengan teori yang menyatakan bahwa nilai tukar memiliki pengaruh yang negatif signifikan terhadap indeks harga saham. Hal ini dapat dijelaskan bahwa sebagian besar emiten-emiten yang tergabung dalam indeks harga saham LQ-45 berorientasi perusahaan pengekspor. Perusahaan yang memiliki orientasi usaha pengekspor, peningkatan nilai tukar (depresiasi) justru akan menyebabkan pendapatan perusahaan menjadi naik karena harga komoditas yang diperdagangkan meningkat. Meningkatnya pendapatan perusahaan tersebut akan berdampak pada peningkatan harga saham perusahaan sehingga indeks harga saham juga ikut mengalami peningkatan. Hasil penelitian ini sejalan dengan Handiani (2014) yang menemukan bahwa nilai tukar berpengaruh positif terhadap indeks harga saham. Namun, hasil penelitian ini berbeda dengan Situngkir \& Batu (2020) yang menyatakan bahwa nilai tukar memiliki pengaruh yang negatif terhadap indeks harga saham.

Pengujian koefisien regresi pada variabel cadangan devisa mendapatkan hasil perhitungan $t_{\text {hitung }}$ sebesar 8.429 dengan tingkat signifikansi 0.000 . Hasil pengujian ini memberikan kesimpulan bahwa cadangan devisa berpengaruh positif signifikan terhadap indeks harga saham LQ-45 di Bursa Efek Indonesia. Hal ini disebabkan karena peningkatan cadangan devisa menunjukkan terjadinya surplus neraca 
pembayaran. Neraca pembayaran yang meningkat mengindikasikan bahwa dunia usaha yang dilakukan oleh emiten-emiten dengan saham terliquid menunjukkan peningkatan. Meningkatnya kinerja inilah yang menyebabkan pendapatan perusahaan menjadi ikut meningkat, sehingga perusahaan mampu memberikan imbal hasil yang lebih besar kepada investor. Hasil penelitian ini sejalan dengan Mikial (2014) bahwa cadangan devisa berpengaruh positif terhadap indeks harga saham. Namun, hasil penelitian ini memiliki perbedaaan dengan penelitian yang dilakukan oleh Rizky (2018) yang menyatakan bahwa cadangan devisa memberikan pengaruh yang negatif terhadap indeks harga saham.

Pengujian koefisien regresi pada variabel harga emas diperoleh hasil perhitungan $t_{\text {hitung }}$ sebesar -1.301 dengan tingkat signifikansi sebesar 0,196. Hasil pengujian ini menunjukkan bahwa harga emas memberikan dampak yang negatif namun tidak signifikan terhadap indeks harga saham LQ-45 di Bursa Efek Indonesia. berdasarkan hasil penelitian kenaikan harga emas tidak memberikan pengaruh yang signifikan terhadap indeks harga saham. Hal ini dapat dijelaskan bahwa kenaikan harga emas tidak selalu mempengaruhi sikap seluruh investor yang terdapat di Bursa Efek Indonesia. Investor yang memiliki sikap pesimis dengan mengharapkan keuntungan yang lebih besar akan memilih berinvestasi saham daripada emas. Oleh karena itu, kenaikan harga emas tidak mempengaruhi indeks harga saham. Hasil penelitian ini sejalan dengan Venkatraja (2014) bahwa harga emas memberikan pengaruh yang negatif terhadap harga saham. Namun, penelitian Lestari (2016) menemukan hasil yang berbeda bahwa harga emas akan memberikan pengaruh yang positif terhadap indeks harga saham.

\section{Uji F}

Hasil pengujian uji $\mathrm{F}$ pada model persamaan regresi menemukan bahwa hasil perhitungan diperoleh nilai $\mathrm{F}_{\text {hitung }}$ sebesar 216.107 dengan tingkat signifikansi

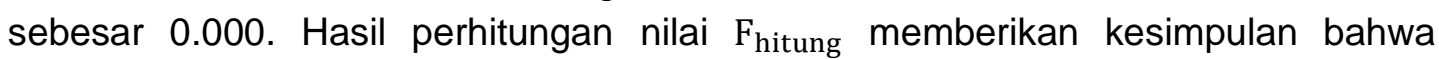
secara simultan suku bunga, nilai tukar, cadangan devisa, dan harga emas berpengaruh signifikan terhadap indeks harga saham LQ-45 di Bursa Efek Indonesia.

\section{KESIMPULAN}

Berdasarkan hasil dan pembahasan penelitian mengenai pengaruh variabel makro ekonomi yaitu suku bunga, nilai tukar, cadangan devisa, dan harga emas terhadap indeks harga saham LQ-45 di Bursa Efek Indonesia, peneliti dapat memberikan kesimpulan diantaranya :

1. Suku bunga berpengaruh negatif serta signifikan terhadap indeks harga saham LQ-45 di Bursa Efek Indonesia.

2. Nilai tukar berpengaruh positif signifikan terhadap indeks harga saham LQ-45 di Bursa Efek Indonesia.

3. Cadangan devisa berpengaruh positif signifikan terhadap indeks harga saham LQ-45 di Bursa Efek Indonesia. 
4. Harga emas berpengaruh negatif tidak signifikan terhadap indeks harga saham LQ-45 di Bursa Efek Indonesia.

5. Suku bunga, nilai tukar, cadangan devisa, dan harga emas berpengaruh terhadap indeks harga saham LQ-45 di Bursa Efek Indonesia.

Variabel makro ekonomi memberikan pengaruh yang signifikan terhadap harga saham, sehingga investor harus mengetahui dan mampu memprediksi keadaan makro ekonomi sebelum berinvestasi saham. Pemerintah dapat meningkatkan perluasan investasi dengan cara melakukan pelonggaran kebijakan makro ekonomi penerapan menurunkan tingkat suku bunga, sehingga investasi saham di Indonesia mengalami perkembangan yang baik. Peneliti berharap bagi penelitian selanjutnya untuk menambahkan variabel makro ekonomi seperti tingkat pengangguran, indeks pembangunan manusia, dan hutang luar negeri dengan harapan mampu menganalisis pergerakan harga saham yang lebih representatif.

\section{DAFTAR PUSTAKA}

(1) Akbar, AJ., Yuliana, S., Marwa, T. (2016). Pengaruh Nilai Tukar Rupiah, Suku Bunga SBI, dan Inflasi Terhadap Indeks Harga Saham Gabungan (IHSG) Sektor Pertanian di Bursa Efek Indonesia. Jurnal Ekonomi Pembangunan, Vol. 14 (2), 2016 : 47-53. https://doi.org/10.29259/jep.v14i2.8812

(2) Andriyani, I., Armereo, C. (2016). Pengaruh Suku Bunga, Inflasi, Nilai Buku Terhadap Harga Saham Perusahaan Indeks LQ45 yang Terdaftar di Bursa Efek Indonesia (BEI). Jurnal IImiah Orasi Bisnis Vol 15 Bulan Mei 2016. https://jurnal.polsri.ac.id/index.php/admniaga/article

(3) Asmara, IPWP., Suarjaya, AAG. (2018). Pengaruh Variabel Makro Ekonomi Terhadap Indeks Harga Saham Gabungan. E-Jurnal Manajemen Unud, Vol.7(3), 2018 : 13971425. https://doi.org/10.24843/EJMUNUD.2018

(4) Gujarati, DN. Porter, DC. (2015). Dasar-Dasar Ekonometrika. Edisi 5 - Buku 1. Jakarta : Salemba Empat

(5) Handiani, S. (2014). Pengaruh Harga Emas Dunia, Harga Minyak Dunia dan Nilai Tukar Dolar Amerika/Rupiah Terhadap Indeks Harga Saham Gabungan Pada Periode 20082013. E-Journal Graduate Unpar Part A - Economics, Vol. 1 (1), 2014 : 85-93. http://journal.unpar.ac.id

(6) Hsing, Y., Hsieh, W. (2012). Impacts of Macroeconomic Variables On The Stock Market Index in Poland: New Evidence. Journal of Business Economics and Management, Vol 13 (2), 2012: 334-343. http://dx.doi.org/10.3846/16111699.2011.620133

(7) Iglesias, EM., Haughton, AY. (2013). Interaction Between Monetary Policy and Stock Prices: A Comparison Between the Caribbean and the US. Journal Applied Financial Economics, Vol. 23, 2013: 515-534. http://dx.doi.org/10.1080/09603107.2012.730131

(8) Jauhari, MAH. (2018). Pengaruh Perubahan Inflasi, Suku Bunga, Kurs dan Pertumbuhan PDB Terhadap Indeks LQ-45. Skripsi. Indralaya: Jurusan Manajemen Universitas Sriwijaya.

(9) Kusumawardhani, S. (2018). Analisis Pengaruh Variabel Makroekonomi Terhadap Indeks Harga Saham Gabungan Periode 2008.I - 2016.IV. Skripsi. Surakarta: Program Studi Ekonomi Pembangunan Universitas Muhamadiyah Surakarta.

(10) Lestari, MP. (2016). Pengaruh Faktor Internal dan Faktor Eksternal Terhadap Harga Saham Perusahaan pada Indeks LQ-45. Jurna Ilmu Manajemen, Vol 4 (1), 2016: 91 102. https://jurnalmahasiswa.unnesa.ac.id 
(11) Mikial, M. (2014). Pengaruh Inflasi, Suku Bunga Bank Indonesia, Harga Minyak Dunia Dan Cadangan Devisa Terhadap Indeks Harga Saham Gabungan. Jurnal Kompetitif, Vol. 3 (2), 2014: 1-13. http://univ-tridinanti.ac.id

(12) Mutira, P. (2019). Adakah Pengaruh Free Float Terhadap Pelaku Pasar Saham di Indonesia?. Jurnal Bisnis dan Akuntansi, Vol. 21 (1), 2019: 39-46. http://jurnaltsm.id/index.php/JBA

(13) Novianto, A. (2011). Analisis Pengaruh Nilai Tukar (Kurs) Dolar Amerika/Rupiah (US\$/Rp), Tingkat Suku Bunga SBI, Inflasi, dan Jumlah Uang Beredar (M2) Terhadap Indeks Harga Saham Gabungan (IHSG) di Bursa Efek Indonesia (BEI) Periode 1999.12010.6. Skripsi. Semarang : Jurusan Ilmu Ekonomi/Studi Pembangunan Universitas Diponegoro.

(14) Nuryasman, MN., Permatasari, V. (2016). Dampak Variabel Makroekonomi dan Indeks Saham Global Terhadap Indeks Harga LQ-45 Di Bursa Efek Indonesia. Jurnal Ekonomi, Vol 21 (03), 2016: 309-324. http://www.ecojoin.org/index.php/EJE/article

(15) Nugraha, MI. (2020). Pengaruh Tingkat Kurs Rupiah, Harga Emas dan Harga Minyak terhadap Indeks LQ 45 Periode Maret 2013-Juni 2016. Jurnal Riset Inspirasi Manajemen dan Kewirausahaan, Vol 4 (2), 2020: 86-90. https://ejurnal.stimibjm.ac.id/index.php/JRIMK diakses pada 10 November 2020.

(16) Pratiwi, E., Hendrawan, R. (2014). Pengaruh Indeks Harga Saham Gabungan, Faktor Ekonomi Makro dan Indeks Dow Jones Industrial Average Terhadap Indeks Harga Saham LQ 45 Periode 2008-2012 dalam Keputusan Investasi. Jurnal Manajemen Indonesia, Vol. 14 (1), 2014 : 17-35. https://doi.org/10.25124/jmi.v14i1.349

(17) Rizky, C. (2018). Pengaruh Inflasi, Suku Bunga Acuan, Kurs dan Cadangan Devisa Terhadap Pergerakan Jakarta Islamic Index (Januari 2013 - Desember 2017). Skripsi. Medan : Fakultas Ekonomi dan Bisnis UIN Sumatera Utara.

(18) Silim, L. (2013). Pengaruh Variabel Ekonomi Makro Terhadap Indeks Harga Saham Gabungan pada Bursa Efek Indonesia Periode 2002-2011. Jurnal IImiah Mahasiswa Universitas Surabaya, Vol. 2 (2), 2013 : 1-18. https://journal.ubaya.ac.id

(19) Santoso, S. (2012). Analisis SPSS pada Statistik Parametik. Jakarta : PT. Elex Media Komputindo.

(20) Sugiyono, (2014). Metode Penelitian Pendidikan Pendekatan Kuantitatif, Kualitatif, Dan R\&D. Bandung: Alfabeta

(21) Sholikin, M. (2016). Pengaruh Variabel Makro Ekonomi Terhadap Indeks Harga Saham LQ-45. Skripsi. Surabaya : Jurusan Manajemen Sekolah Tinggi Ilmu Ekonomi Perbanas.

(22) Sunardi, N., Ula. LNR. (2017). Pengaruh BI Rate, Inflasi dan Kurs Terhadap Indeks Harga Saham Gabungan (IHSG). Jurnal SEKURITAS (Saham, Ekonomi, Keuangan, dan Investasi), Vol.1 (2), 2017 : 27-41. http://openjurnal.unpam.ac.id

(23) Situngkir, TL., Batu, RL. (2020). Pengaruh Inflasi dan Nilai Tukar Terhadap Indeks Harga Saham LQ45. Jurnal Sentralisasi, Vol 9 (1), 2020: 36-44. https://doi.org/10.33506/sl.v9i1.708

(24) Venkatraja, B. (2014). Impact Of Macroeconomic Variables On Stock Market Performance In India: An Empirical Analysis. International Journal of Business Quantitative Economics and Applied Management Research, Vol 1 (6), 2014: 71-85.

(25) Wulandari. Saleh, S. (2015). Interaksi Dinamis Variabel Makroekonomi Terhadap Return Saham di Bursa Efek Indonesia. Jurnal Ekonomi dan Studi Pembangunan Vol 16 (1), $2015:$ 99-118.

(26) Yanita., Wahyuddin. (2010). Pengaruh Inflasi, Kurs Rupiah-Dollar (Rp/\$), dan Tingkat Suku Bunga Deposito Terhadap Indeks LQ45 di Bursa Efek Indonesia. Jurnal Ekonomi Manajemen Sumber Daya, Vol. 11 (1), 2010 : 65-76. https://publikasiilmiah.ums.ac.id 
(27) Zakaria., Aminu, A., Pattiasina, V. (2018). Determinan Indeks Harga Saham Gabungan (IHSG) di Bursa Efek Indonesia. Jurnal Manajemen dan Akuntansi, Vol. 5 (2), 2018: 119 131. http://jurnal.uniyap.ac.id

(28) https://www.bi.go.id/indikator_moneter, diakses 10 November 2020.

(29) https://m.id.investing.com/, diakses 10 November 2020.

(30) https://www.idx.co.id, diakses 10 November 2020.

(31) https://www.statistik.kemendag.go.id, diakses 10 November 2020. 